\title{
可視光でアンケージング可能なキノリニウム型ケージド神経伝達物質の創製と応用
}

\author{
鳴海哲夫
}

\section{Novel Visible Light Photoactivatable Caged Neurotransmitters Based on a $N$-Methyl Quinolinium Chromophore}

\author{
Tetsuo Narumi \\ Graduate School of Integrated Science and Technology, Shizuoka University; \\ 3-5-1 Johoku, Naka-ku, Hamamatsu 432-8561, Japan.
}

(Received August 10, 2018)

\begin{abstract}
The development of novel photolabile protecting groups with practical levels of photolytic efficiency and hydrophilicity can provide smart photochemical tools, such as caged compounds. One of the long-standing problems of most reported photolabile protecting groups is the requirement for one-photon activation, of ultraviolet light $(250-400 \mathrm{~nm})$, that is harmful to living cells and has low tissue penetration power. An attractive approach to overcome this would be the use of longer-wavelength light for one-photon activation; advantages would include both lower phototoxicity and higher tissue penetration power than UV irradiation. As part of our research aimed at developing new photochemical tools, we have developed the $N$-methyl-7-hydroxyquinolinium ( $N$-Me-7-HQm) caging chromophore as a novel photocage, sensitive to visible light. A key to the success of the development of the $N$-Me-7-HQm photocage was simple $N$ methylation of the 7-hydroxyquinoline chromophore. This modification allows access to visible light absorbance, facile photoactivation by blue-LED light $(458 \mathrm{~nm})$ with high photolytic efficiency, excellent water solubility, and high resistance to spontaneous hydrolysis. The success of the late stage upgrading of a chromophore in the synthetic sequence suggests that further functionalization of the caging chromophore will be possible, and should aid in the rapid generation of structurally diverse libraries of visible light-sensitive photocages.
\end{abstract}

Key words_ — photolabile protecting group; caged compound; blue light photoactivation

\section{1. はじめに}

ケージド化合物は，その活性が有機化学的に付与 された「カゴ (cage)」によって一時的に閉じ込め られており，特定の条件によって「カゴを外す (uncage)」ことでもとの活性を発揮する機能性分子 である，特に，温和な条件下，侵襲性が低く，迅速 に反応が進行する光刺激を用いるケージド化合物が 汎用されている。これら光刺激を用いるケージド化 合物は，生物活性分子の機能発現に重要な官能基に 対し, 光照射で活性化（脱保護）可能な光感受性保 護基を結合させることで，その活性のオフ／オンを 保護／脱保護で制御するものであり，その特性は光

静岡大学大学院総合科学技術研究科工学専攻化学バイ オ工学コースバイオ応用工学分野（干432-8561 浜松市 中区城北 3-5-1)

e-mail: narumi.tetsuo@shizuoka.ac.jp

本総説は, 日本薬学会第 138 年会シンポジウムS58 で 発表した内容を中心に記述したものである.
感受性保護基に大きく影響を受ける。これまでに報 告されている光感受性保護基の多くが，光毒性が懸 念される紫外光をケージ解除に必要とするのに対 し, 近年, 光毒性の低い可視光を高効率で利用可能 なクロモフォアが見い出され，ケージド化学が可視 光照射による 1 光子励起反応でケージ解除する新た な時代に突入しつつある。

本稿は，筆者らが見い出した可視光でケージ解除 可能なキノリニウム型光感受性保護基の開発と神経 伝達物質への応用について, 日本薬学会第 138 年会 シンポジウムS58 で発表した内容を骨子として, これに少し補足を加えたものである.

2. $N$-メチル-7-ヒドロキシキノリニウム型光感 受性保護基の開発

2-1. $N$-メチル-7-ヒドロキシキノリニウム型クロ モフォアの設計 これまでに多種多用な光感受性 保護基が見い出されており，ニトロベンジル型や二 トロアニリド型，アリールカルボニル型，クマリニ 


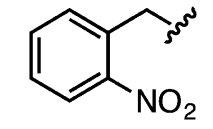

Nitrobenzyl-type $\lambda_{\max }: 260 \sim 350 \mathrm{~nm}$

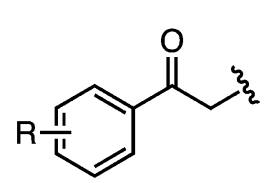

Arylcarbonyl-type $\lambda_{\text {max }}: 300 \sim 350 \mathrm{~nm}$
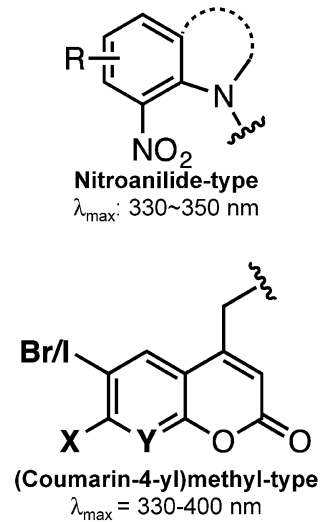

Fig. 1. Representative Chromophore for UV-light Sensitive Caged Compounds

ルメチル型などがおもにケージド化合物に応用され ている (Fig. 1). ${ }^{1-3)}$ 筆者らは汎用されるクマリニ ルメチル型光感受性保護基の問題点を解決するため に研究を進め, クマリン骨格の 8 位に窒素原子を導 入したアザクマリニルメチル型光感受性保護基を開 発した. ${ }^{4-6)}$ 8-アザクマリニルメチル型保護基はもと のクマリニルメチル型保護基に比べ，水溶性が大幅 に向上しており，疎水性の高い生理活性分子のケー ジド化に有用である. ${ }^{4)}$ さらに窒素原子の誘起効果 によってフェノール性水酸基の酸性度が向上するこ とから，クマリニルメチル型保護基では利用できな かったヨウ素原子に起因する重原子効果によって極 めて高い光反応性を示すことが特徵である. ${ }^{6}$

一方で，アザクマリニルメチル型光感受性保護基 の開発過程でみえてきた課題として, 光活性化には 紫外光を必要とすることが挙げられる。紫外光は工 ネルギーが大きいため，結合開裂を伴う光感受性保 護基の脱保護にしばしば用いられるものの，その大 きなエネルギーによって細胞にダメージを与えるこ とが縣念される．また，紫外光は組織透過性が低い ことから，その利用は in vitro レベルに限定される ことも課題となる．筆者らが光感受性保護基の開発 研究に着手した当時, この紫外光を利用する光活性 化の問題は，アザクマリニルメチル型保護基に限定 されるものではなく，これまでに報告されているほ とんどの光感受性保護基に共通した問題であった. 最も直接的な解決策は, 光毒性の低い長波長光を用 いることであり，赤色から近赤外光による 2 光子励 起によるケージ解除可能なクロモフォアが見い出さ れ，ニトロベンジル型やクマリニルメチル型など,
その有用性が明らかにされている. ${ }^{7)}$ 一方で, 2 光 子励起によるケージ解除は, 高密度レーザーや特別 な実験環境を必要とすることから実用性に欠けると も言える。そこで，筆者らは高額な機器や特別な実 験環境を必要とせず安価な光源として LED を利用 可能な可視光による 1 光子励起反応に着目した. ${ }^{8)}$ 本稿にて紹介するキノリニウム型光感受性保護基の 研究に着手した 2015 年当時の分子設計指針を要約 すると以下の通りである.

1）青色光によるケージ解除

可視光による 1 光子励起可能なクロモフォアとし て RuBi 型9) を始め, BODIPY 型10,11) やクマリニル メチル型保護基12-14)が相ついで報告されたが, 研究 の独創性を求めて, これらとは異なる構造的な特徵 を持ち, かつ安価に LED 光源が入手可能な $450 \mathrm{~nm}$ 付近の青色光を吸収する骨格をクロモフォアとする.

2) 高い光反応効率

一般にケージド化合物の有用性は, 光反応の量子 収率と励起波長におけるモル吸光係数の積で求めら れるケージ解除効率 (光反応効率) で評価するため,

（予測は難しいものの）量子収率並びにモル吸光係 数それぞれを大きな值とすることで，高い光反応効 率を示す骨格をクロモフォアとする.

3）合成後期官能基化

可視光で活性化されるケージド化合物の化学合成 において，可視光を吸収する化合物から合成を開始 した場合，その後のすべての実験操作を遮光条件に て行う必要があり, 操作性が著しく低下する，そこ で，合成後期に化学修飾又は官能基化することで吸 収波長が長波長化できる拡張性のあるクロモフォア とする.

以上の設計指針に基づいて，筆者らは7-ヒドロ キシキノリン（7-hydroxy-quinoline; 7-HQ）骨格と 1 位窒素原子を $N$-アルキル化した $N$-アルキル-7-ヒ ドロキシキノリニウム（7-hydroxyquinolinium; 7-HQm）骨格に着目した（Fig. 2).

7-HQ を基本骨格とする光感受性保護基として, Dore らは 8 位に臭素原子を導入した 8-bromo-7hydroxyquinoline-2-ylmethyl (BHQ) 基15) 8 位に シアノ基を導入した 8-cyano-7-hydroxyquinoline-2ylmethyl (CyHQ) 基16)などを開発している。これ ら 7-HQ 型光感受性保護基は光反応の量子収率が高 いものの, 吸収極大波長は紫外領域であり, 吸収極 


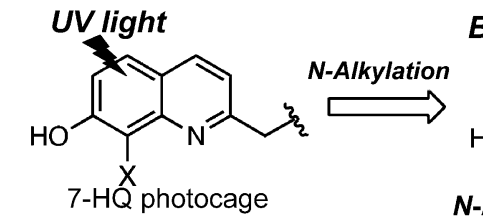

Blue light (458 $\mathrm{nm})$

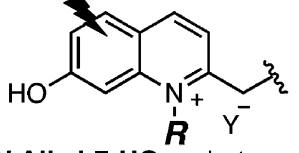

N-Alkyl-7-HQm photocage

$\checkmark$ UV light photoactivation

$\checkmark$ Low molar absorptivity

$\checkmark$ Efficient 1-Photon Photolysis

$\checkmark$ Blue light photoactivation $\checkmark$ High molar absorptivity

$\checkmark$ High photolytic efficiency

Fig. 2. Design of $\mathrm{N}$-Alkyl-7-hydroxyquinolinium Chromophore

大波長におけるモル吸光係数が小さいために, 光反 応効率（光反応の量子収率とモル吸光係数の積）は 低下することが課題と言える。これに対し，1位窒 素原子を $N$-アルキル化した 7-HQm 骨格は，光学 pH センサー17)や蛍光色素18,19)に用いられており, 青色光を吸収し，大きなモル吸光係数を持つことが 報告されている．また，7-HQ 骨格は $\mathrm{sp}^{2}$ 混成軌道 を形成する窒素原子が非共有電子対を有しているた め， N-アルキル化反応によって更なる誘導体化が 可能であり，合成後期官能基化を可能にすると期待 された。つまり，吸収極大波長が紫外領域にある 7-HQ で合成を始め, 生物活性分子とカップリング したのち，N-アルキル化によって 7-HQm に誘導す ることで, 合成の最終段階で可視光活性化能を付与 できると考えた。しかも，N-アルキル化された 7-HQm は安定なカチオン種であり, アルキル化剂 に由来するアニオン種とイオン対を形成する有機塩 となるため，ケージド化合物でしばしば問題となる 水溶性の問題も解決できると考えた.

2-2. $N$-アルキル-7-ヒドロキシキノリニウム化合 物の合成之光学特性 まず，7-HQm 骨格の有用 性を検証するために，7-ヒドロキシ-2-メチルキノ リンに対し種々のアルキル化剂を作用させ，得られ た $N$-アルキルキノリニウム化合物の光学特性を評 価した（Table 1)。7-ヒドロキシ-2-メチルキノリン (1) の吸収極大波長が $330 \mathrm{~nm}$ 付近であるのに対し, $N$-アルキルキノリニウム化合物（2-7）の吸収極大 波長は 400-425 nm 付近であり，期待した通り青色 光を吸収することが明らかになった。さらに, $N$-アルキル化することで 7-HQ 型光感受性保護基 の課題であったモル吸光係数も増大し，N-メチル 体（2）のモル吸光係数は 7-ヒドロキシ-2-メチルキ ノリンの約 4 倍, $N$-ベンジル体（3） では約 6 倍増
Table 1. $N$-Alkyl Effect on Photophysical Properties
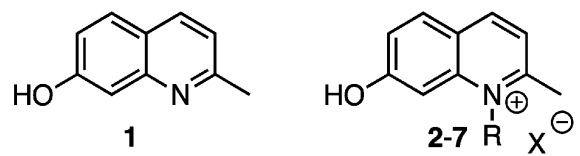

\begin{tabular}{ccccc}
\hline \hline compd & $\mathrm{R}$ & $\mathrm{X}$ & $\begin{array}{c}\lambda_{\max } \mathrm{a}^{(} \\
(\mathrm{nm})\end{array}$ & $\begin{array}{c}\varepsilon_{\max } \mathrm{b} \\
\left(\mathrm{M}^{-1} \mathrm{~cm}^{-1}\right)\end{array}$ \\
\hline $\mathbf{1}$ & - & - & 330 & 3200 \\
$\mathbf{2}$ & $\mathrm{CH}_{3}$ & $\mathrm{I}$ & 425 & 12300 \\
$\mathbf{3}$ & $\mathrm{CH}_{2} \mathrm{Ph}$ & $\mathrm{Br}$ & 410 & 19100 \\
$\mathbf{4}$ & $\mathrm{CH}_{2} \mathrm{CO}_{2} \mathrm{Et}$ & $\mathrm{Br}$ & 412 & 11000 \\
$\mathbf{5}$ & $\mathrm{CH}_{2} \mathrm{CO}_{2} \mathrm{H}$ & $\mathrm{Br}$ & 410 & 12200 \\
$\mathbf{6}$ & $\mathrm{CH}_{2} \mathrm{C}(\mathrm{O}) \mathrm{Ph}$ & $\mathrm{Br}$ & 403 & 6600 \\
$\mathbf{7}$ & $\mathrm{CH}_{2} \mathrm{C}(\mathrm{O}) \mathrm{Ph}(\mathrm{pBr})$ & $\mathrm{Br}$ & 408 & 4000
\end{tabular}

${ }^{a}$ Long-wavelength of absorption maxima in PBS (0.1\% DMSO), ${ }^{b}$ molar absorptivity at absorption maxima.

大した。これらの結果より，7-HQ 骨格の $N$-アル キル化は可視光による光感受性保護基の創製におい て有用な分子変換であることが明らかになった．合 成した $N$-アルキルキノリニウム化合物の中で最も 長波長光を吸収し，7-ヒドロキシ-2-メチルキノリ ンよりも約 4 倍大きなモル吸光係数を持つ $N$-メチ ル-7-ヒドロキシキノリニウム（N-Me-7-HQm）骨 格を用いてその後の研究を進めた.

2-3. $N$-Me-7-HQm 型ケージド酢酸の光化学的 性質単純な構造を有するケージド化合物として, $N$-Me-7-HQm 型ケージド酶酸（9）を合成し，青色 光照射による 1 光子励起反応条件下での光化学的性 質を調べた。 7-ヒドロキシ-2-メチルキノリンから 5 工程で誘導したキノリンメチルエステル（8）に対 し，トリフルオロメタンスルホン酸メチルを用いて $N$-メチル化し，水中加熱条件下 TBDPS 基を脱保護 した後に HPLC にて精製することで，所望の $N$ Me-7-HQm 型ケージド酢酸（9）を合成した (Scheme 1)。得られた $N$-Me-7-HQm 型ケージド酢 酸（9）をPBS に溶解させ，青色 LED を作用させ たところ，炭素一酸素結合開裂を伴う光分解反応が 進行し, 対応するキノリニウムメチルアルコール （10）の生成が HPLC で確認できた [Fig. 3(b)]. $458 \mathrm{~nm}$ 光照射時の光反応の量子収率 $\left(\Phi_{\mathrm{chem}}\right)$ は 0.045 ，そのときの反応効率 $\left(\Phi_{\mathrm{chem}} \cdot \varepsilon_{458}\right)$ は 234 であり, 経験的ではあるものの, 1 光子励起反応に おける反応効率の指標 $\left(\Phi_{\text {chem }} \cdot \varepsilon>100\right)^{20,21)}$ を超え るケージド化合物であることが明らかになつた。

さらに，キノリニウム骨格における置換基効果を 


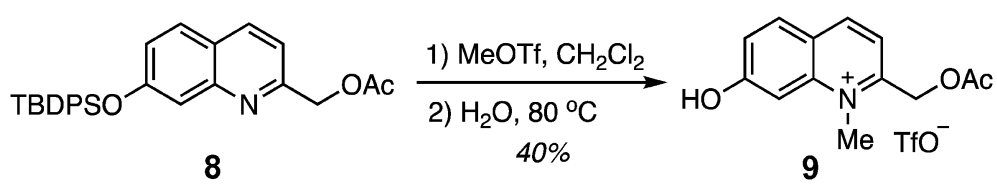

Scheme 1. Synthesis of N-Me-HQm-type Caged Acetate (9)

a

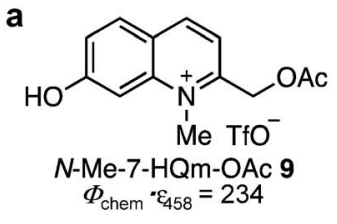

b

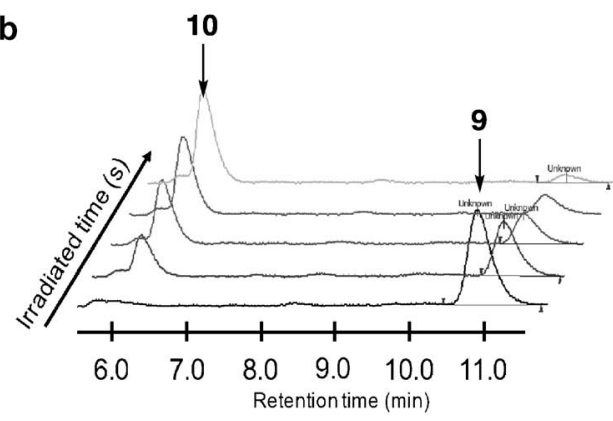

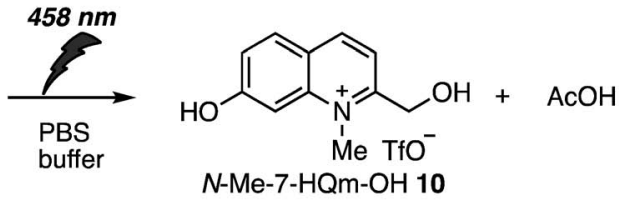

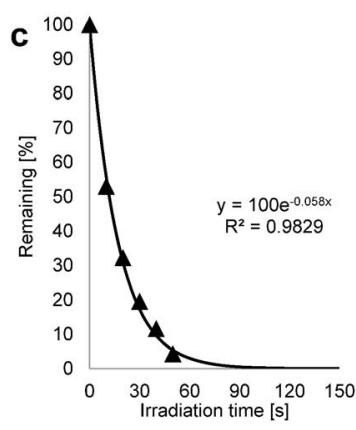

Fig. 3. a) Photolysis of $N$-Me-7-HQm-OAc (9) , b) HPLC Analyses for the Photolysis Reaction of 9 at $458 \mathrm{~nm}$ in PBS Buffer (pH 7.4, containing $0.1 \%$ DMSO), and c) Time Courses of the Photolysis Reaction of 9

検討したところ，7 位ヒドロキシ基をメトキシ基に 置換した $N-\mathrm{Me}-7-\mathrm{MQm}$ 型（11）は吸収極大波長が 紫外領域にあるため $\left(\lambda_{\max }=357 \mathrm{~nm}\right), 458 \mathrm{~nm}$ 光照 射では光反応が進行しなかった（Fig. 4)。また，7 位ヒドロキシ基をジメチルアミノ基に置換した $N$ Me-7-DMAQm 型（12）は， $N$-Me-7-HQm 型に比 ベ, 吸収極大波長が約 $30 \mathrm{~nm}$ 長波長化し（ $\lambda_{\text {max }}=$ $449 \mathrm{~nm})$, モル吸光係数も約 1.4 倍増大したものの $\left(\varepsilon_{458}=7400 \mathrm{M}^{-1} \mathrm{~cm}^{-1}\right)$, 光反応の量子収率が 0.0012 となり, 光反応効率は大幅に低下した $\left(\Phi_{\text {chem }} \cdot \varepsilon_{458}=8.9\right)$. $N$-Me-7-DMAQm 型の 4 位に 電子供与性エチル基を導入することで，わずかに光 反応性の改善はみられたものの, その反応効率 $\left(\Phi_{\text {chem }} \cdot \varepsilon_{458}\right)$ は 29 であり, $N$-Me-7-MQm 型の約 $1 / 8$ 程度であった。これらの結果より， 7 位ヒドロ キシ基がキノリニウム骨格の光反応性に大きく寄与 していることが明らかになった。これは 7 位ヒドロ キシ基を有する $N$-アルキルキノリニウム化合物の 基底状態における $\mathrm{p} K_{\mathrm{a}}$ は 5-6 付近であるものの, 励起状態においては酸性度が大幅に向上し, ${ }^{22}$ ヒトト ロキシアニオン型になるため, その電子供与性によ り分子内電荷移動が起こり易くなったものと考えて
いる.

3. $N$-メチル-7-ヒドロキシキノリニウム型ケー ジドアミノ酸

3-1. $N$-Me-7-HQm 型ケージドアミノ酸の合成 アミノ酸は生体の至るところに存在し, タンパク 質を合成する最小単位の構成成分であることに加 え，それ自体が生体のエネルギ一産生を始め，筋肉 の維持や増強, 学習機能, 生体の恒常性維持, 神経 伝達など，多くの生体機能に関与している. よつ て，アミノ酸が有するアミノ基やカルボキシ基，側 鎖官能基を光感受性保護基で保護したケージドアミ ノ酸は, これらアミノ酸が関与する生体内反応を高 い時空間分解能で制御可能な光機能性分子となる. 最も広く用いられているケージドアミノ酸は, 興奮 性シナプス後部の主たる神経伝達物質として機能す るグルタミン酸に保護基が結合したケージドグルタ ミン酸であり, MNI 型, ${ }^{23)} \mathrm{Bhc}$ 型, ${ }^{24)} \mathrm{RuBi}$ 型9)など が報告されており，神経科学分野において広く用い られている. そこで，N-Me-7-HQm 型光感受性保 護基をグルタミン酸に応用した $N$-Me-7-HQm 型 ケージドグルタミン酸の合成に着手した.

先述したケージド酢酸の結果を踏まえ，まずグル 
a

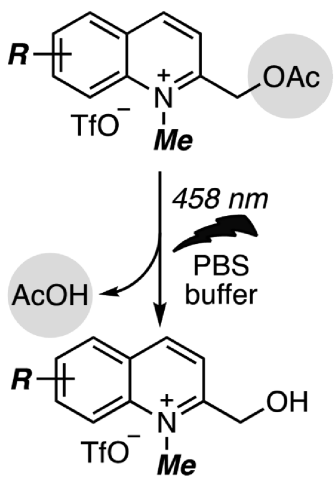

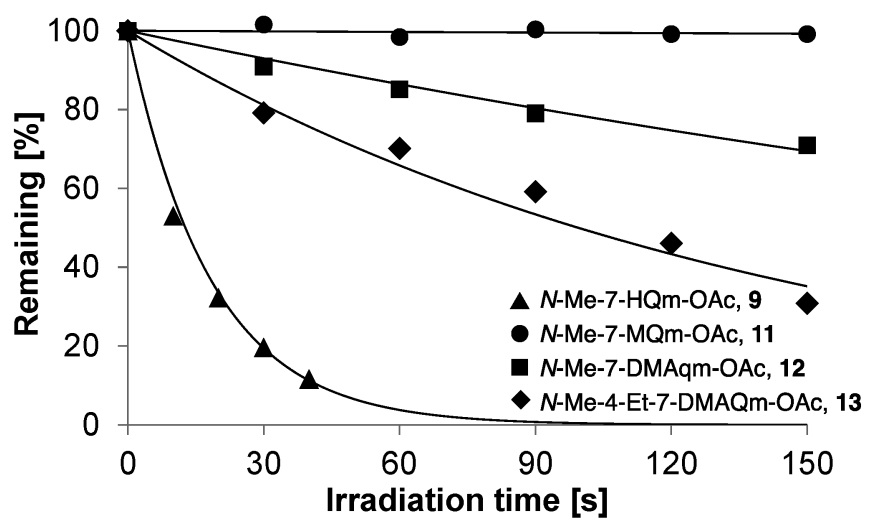

b
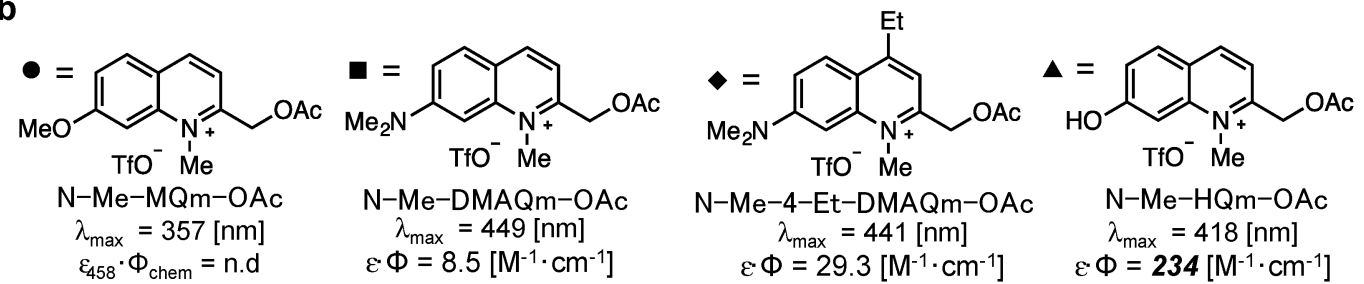

\section{Photosensitivity}

Fig. 4. a) Time Courses of the Photolysis Reaction of N-Me-HQm-type Caged Acetates 9-13, and b) Photosensitivtiy of 9-13

タミン酸の $\alpha$-カルボキシ基に $N$-Me-7-HQm 型光感 受性保護基をエステル型で導入することを検討した. $N$-Me-7-HQm 型ケージド酢酸と同様に，対応する アルコールから $N$-Me-7-HQm 型エステル化合物を 合成し， $N$-Me-7-HQm 型エステル化合物を含む水 溶液に青色 LED を作用させたところ，光分解反応 が進行することを確認した。しかしながら，分取 HPLC にて $N$-Me-7-HQm 型エステル化合物の精製 を試みたものの，予想に反して， $0.1 \% \mathrm{TFA}$ を含む アセトニトリル／水混合溶媒による通常の分取条件 では速やかに自発的加水分解が起きてしまい，単離 精製は困難であった。これはキノリニウムメチルア ルコールの脱離能が高いため, N-Me-7-HQm 型エ ステルの反応性が高くなり，水中では容易に加水分 解されるものと考察しているが，先述したケージド 酢酸においては PBS 中 12 時間後でも自発的加水分 解は $5 \%$ 程度に留まったことから，グルタミン酸の 骨格に由来する影響の可能性も否定できない。この 結果を踏まえ, $N$-Me-7-HQm 型光感受性保護基を エステル型ではなく, より加水分解され難いカーバ メート型で導入することを検討した（Scheme 2).

アルコール（14）に対し，カルボジイミダゾール (CDI) を作用させた後, $\mathrm{H}-\mathrm{Glu}\left({ }^{t} \mathrm{Bu}\right)-\mathrm{O}^{t} \mathrm{Bu} ・ \mathrm{HCl}$ をトリエチルアミン存在下作用させることで，カー
バメート体（15）へと誘導した，続いて，遮光条件 下 $N$-メチル化し， TBDPS 基及び tert-ブチル基を 脱保護した後に HPLC にて精製することで， $\alpha$-ア ミノ基に $N$-Me-7-HQm 型光感受性保護基を導入し た $N$-Me-7-HQm 型ケージドグルタミン酸（16）を 合成した。本合成法を用いることで種々のケージド アミノ酸の調製が可能であり，抑制性神経伝達物質 であるグリシンや $\gamma$-アミノ酪酸（gamma-aminobutyric acid; GABA）のケージドアミノ酸（17-18) を始め, リジン側鎖の $\varepsilon$-アミノ基に $N-\mathrm{Me}-7-\mathrm{HQm}$ 型光感受性保護基を有するケージドリジン（20) を 合成した。

3-2. $N$-Me-7-HQm 型ケージドアミノ酸の光化 学的性質 合成した $N$-Me-7-HQm 型ケージドア ミノ酸の青色光照射による 1 光子励起反応条件下で の光化学的性質を調べた (Table 2).N-Me-7-HQm 型光感受性保護基の導入方法をエステル型からカー バメート型に変換しても, 光化学的性質に大きな影 響を与えず，吸収極大波長は $415 \mathrm{~nm}$ 付近であり， 励起波長 $458 \mathrm{~nm}$ におけるモル吸光係数は 2500$4800 \mathrm{M}^{-1} \mathrm{~cm}^{-1}$ となった。 $N$-Me-7-HQm 型ケージ ドグルタミン酸（16）を PBSに溶解させ，青色 LED を作用させたところ，期待した通り光分解反 応が進行し，対応するキノリニウムメチルアルコー 


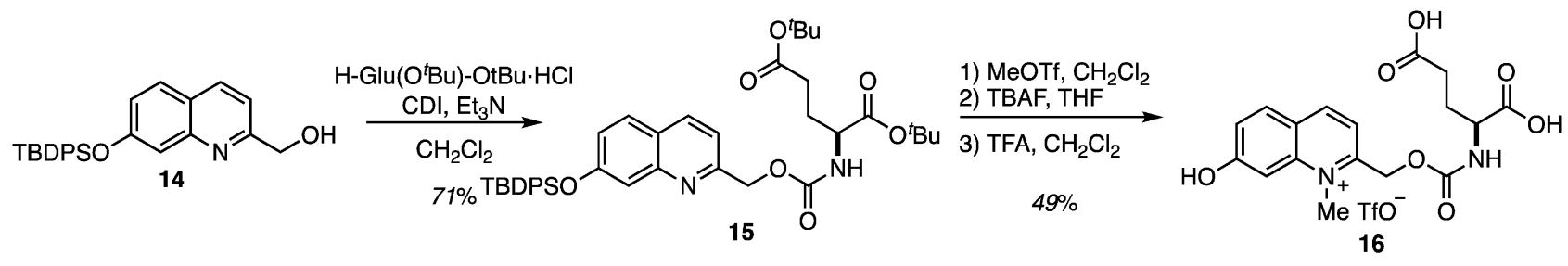<smiles>O=C(O)CNC(=O)OCc1ccc2ccc(O)cc2[n+]1[O-]</smiles><smiles>O=C(O)CCCNC(=O)OCc1ccc2ccc(O)cc2[n+]1[O-]</smiles>
$32 \%$ in 4 steps<smiles>[Y4]C(NC(=O)OCc1ccc2ccc(O)cc2[n+]1[O-])C(=O)O</smiles><smiles>O=C(NCCCC(NCC(F)(F)F)C(=O)O)OCc1ccc2ccc(O)cc2[n+]1[O-]</smiles>

Scheme 2. Synthesis of N-Me-7-HQm-caged Amino Acids 16-20

Table 2. Selected Photophysical and Photochemical Properties of Compounds 16-21

\begin{tabular}{cccccc}
\hline \hline compd & $\begin{array}{c}\lambda_{\max }{ }^{\mathrm{a}} \\
(\mathrm{nm})\end{array}$ & $\begin{array}{c}\varepsilon_{458^{\mathrm{b}}} \\
\left(\mathrm{M}^{-1} \mathrm{~cm}^{-1}\right)\end{array}$ & $\begin{array}{c}t_{90}^{\mathrm{c}} \\
(\mathrm{s})\end{array}$ & $\Phi_{\text {chem }^{\mathrm{d}}}$ & $\varepsilon_{458} \cdot \Phi_{\text {chem }} \mathrm{e}^{\mathrm{e}}$ \\
\hline$N$-Me-7-HQm-Glu (16) & 413 & 4800 & 72 & 0.036 & 173 \\
$N$-Me-7-HQm-Gly (17) & 415 & 2500 & 85 & 0.044 & 110 \\
$N$-Me-7-HQm-GABA (18) & 416 & 2500 & 85 & 0.046 & 115 \\
$N$-Me-7-HQm-Ala (19) & 416 & 5400 & 57 & 0.025 & 135 \\
$N$-Me-7-HQm-Lys (20) & 416 & 2000 & 100 & 0.048 & 96 \\
RuBi-Glu (21) & 450 & 4000 & 22 & 0.068 & 272 \\
\hline
\end{tabular}

${ }^{a}$ Long-wavelength of absorption maxima, b molar absorptivity at $458 \mathrm{~nm},{ }^{c}$ time to reach $90 \%$ conversion, ${ }^{d}$ quantum yield for photoreaction irradiated at $458 \mathrm{~nm}$, e photolytic efficiency.

ルの生成が確認できた。 $N$-Me-7-HQm 型ケージド グルタミン酸 (16) では, $458 \mathrm{~nm}$ 光照射時の光反 応の量子収率 $\left(\Phi_{\text {chem }}\right)$ は 0.036 , そのときの反応効 率 $\left(\Phi_{\mathrm{chem}} \cdot \varepsilon_{458}\right)$ は 173 であり，市販されている $\mathrm{RuBi}$ 型ケージドグルタミン酸（21）の光反応効率 $\left(\Phi_{\mathrm{chem}} \cdot \varepsilon_{458}=272\right)$ には劣るものの, 1 光子励起反 応における反応効率の指標を超えるケージド化合物 であることが明らかになった．グルタミン酸に加 え，グリシン (17) や GABA (18)，アラニン (19), リジンのケージド化合物（20）も，期待した通り青 色 LED による 1 光子励起反応が進行し， $458 \mathrm{~nm}$ 光照射時の光反応の量子収率 $\left(\Phi_{\text {chem }}\right)$ は $0.025-$ 0.048 ，そのときの反応効率 $\left(\Phi_{\mathrm{chem}} \cdot \varepsilon_{458}\right)$ は 96135 であり, ケージドグルタミン酸同様に少ない光 量で効率よく光活性化可能なケージド化合物である
ことが明らかになった．特に，リジン側鎖の $\varepsilon$-ア ミノ基に $N$-Me-7-HQm 型光感受性保護基を有する ケージドリジン（20）では，Fmoc 固相合成法に応 用可能な $\alpha$-アミノ基には Fmoc 基を有しており, 可視光活性化能を有するケージドペプチドの合成へ の応用が期待できる.

続いて,$N-\mathrm{Me}-7-\mathrm{HQm}$ 型ケージドグルタミン酸 （16）の有用性を検証するために，約 $1.5 \mathrm{~mm}$ のハ ムを通して，青色光照射による 1 光子励起反応条件 下での光化学的性質を調べた（Fig. 5).N-Me-7$\mathrm{HQm}$ 型ケージドグルタミン酸（16）の PBS 溶液 を石英セルに入れ，光が直接セルにあたらないよう にセル全体をハムで覆い，これに対し青色 LED を 作用させたところ，期待した通り，炭素-酸素結合 開裂を伴う光分解反応が進行した，本系における光 


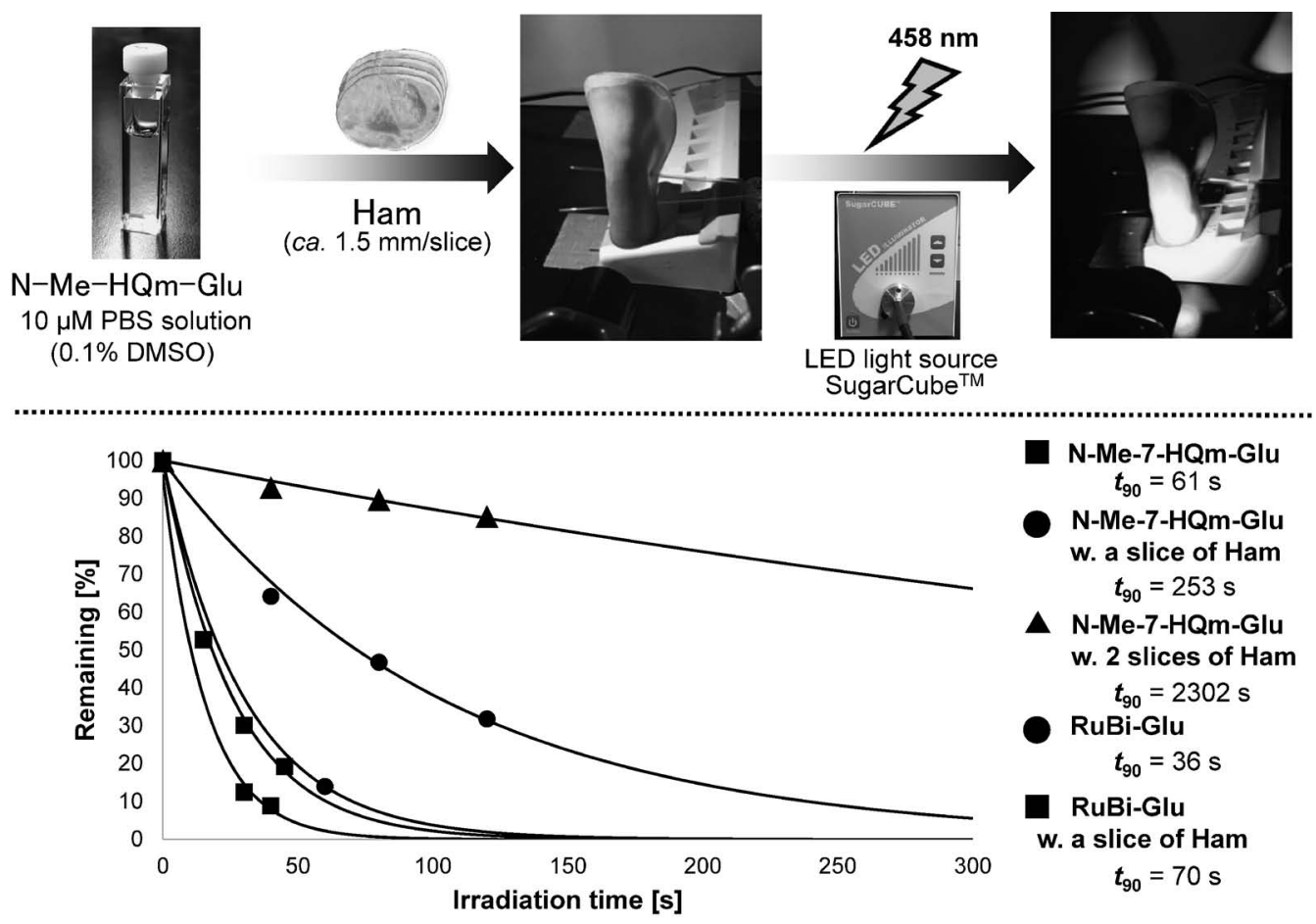

Fig. 5. Time Courses of the Photolysis Reactions of N-Me-7-HQm-Glu (16) and RuBi-Glu (21)

分解反応はハムを用いない条件と同様に 1 次反応で 進行し，ハムの枚数を 1 枚から 2 枚に増やしても光 分解反応は進行した。このことから $N$-Me-7-HQm 型ケージドグルタミン酸はわずかな光量で光活性化 可能なケージド化合物であることが明らかになつた.

さらに，大脳皮質の神経細胞を用いて $N$-Me-7$\mathrm{HQm}$ 型ケージドグルタミン酸（16）の 1 光子励起 反応を検討した。 $N$-Me-7-HQm 型ケージドグルタ ミン酸を人工脳脊髄液に溶解させ，ラット大脳皮質 切片における神経回路を解析したところ， RuBi 型 ケージドグルタミン酸（21） と同様に，細胞刺激後 ミリ秒単位でシナプス応答が記録された [Fig. 6 (a) ]。これは， N-Me-7-HQm 型ケージドグルタミ ン酸（16）のアンケージングにより生成したグルタ ミン酸が，神経細胞上のグルタミン酸受容体を活性 化し，陽イオンを細胞内に流入させることで，神経 細胞の活動電位を誘発したことを示している. 一方 で，同濃度の $N$-Me-7-HQm 型ケージドグルタミン 酸（16）及び RuBi 型ケージドグルタミン酸（21） に対して局所神経回路の解析を行い，各ケージドグ ルタミン酸に対するシナプス応答のピーク振幅をプ ロットした結果， $120 \mu \mathrm{M}$ における $N$-Me-7-HQm 型ケージドグルタミン酸（16）のピーク振幅が同濃
度の $\mathrm{RuBi}$ 型ケージドグルタミン酸（21）のピーク 振幅の約 $1 / 2$ 倍程度となった [Fig. 6(b)]。これは $N-\mathrm{Me}-7-\mathrm{HQm}$ 型ケージドグルタミン酸のアンケー ジングによって生成するグルタミン酸の量が RuBi 型に比べ半分程度であることを示している．以上の 結果より，実用化に向けてさらに改良する必要はあ るものの， N-Me-7-HQm 型ケージドグルタミン酸 が神経細胞内においてもグルタミン酸の放出を制御 可能であり，神経細胞レベルで機能することが示さ れた。

3-3. $\quad N-M e-7-H Q m$ 型ケージドアミノ酸の加水 分解耐性 ケージド化合物に求められる特性とし て, 高い水溶性と $\mathrm{pH} 7$ 付近の水溶液中での自発的 加水分解の起こり難さが求められる。 N-Me-7HQm 型ケージドグルタミン酸（16）の PBS 中に おける飽和濃度は $19 \mathrm{mM}$ となり，水溶性に優れた アザクマリニルメチル型や BHQ 型より高い水溶性 を有することが明らかになった。ささらに，N-Me-7$\mathrm{HQm}$ 型ケージドグルタミン酸（16）の暗所下にお ける加水分解安定性を評価したところ，エステル型 ケージド酶酸では時間経過に伴い自発的加水分解が 起こり，基質の残存率が 12 時間で $96 \%$ まで低下し たのに対し，カルバメート型ケージドグルタミン酸 

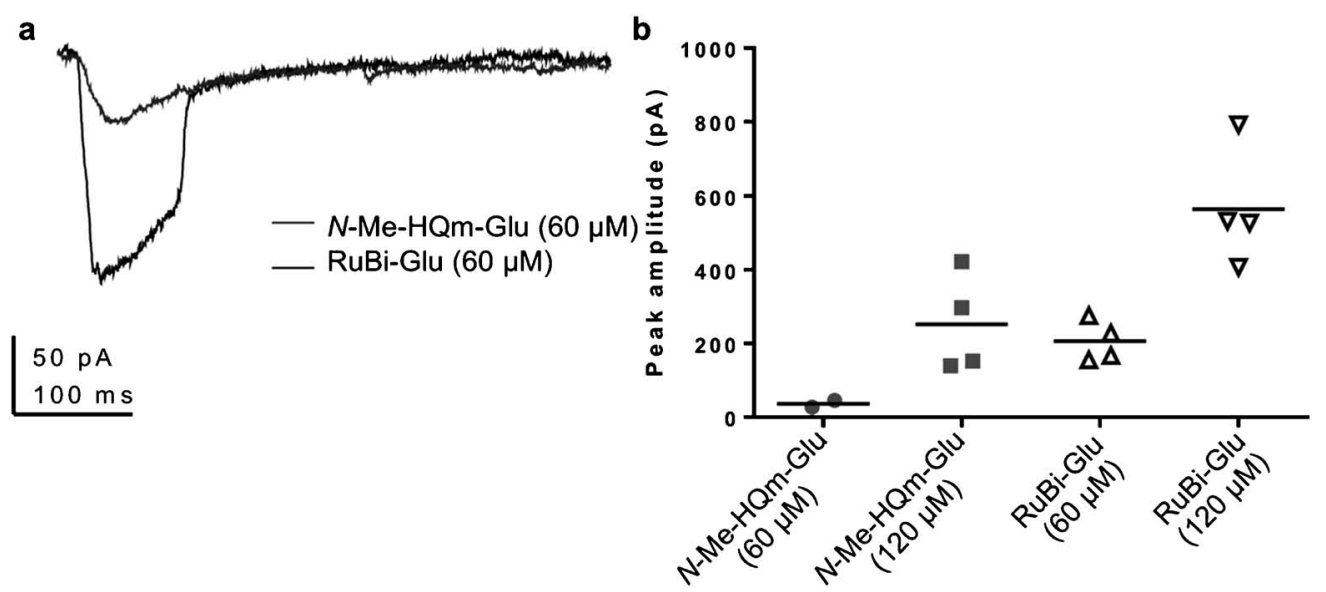

Fig. 6. One-photon Uncaging of $N$-Me-HQm-Glu (16) in Rat Cerebral Cortex Slices

(a) Evoked current responses from uncaging $60 \mu \mathrm{M} N$-Me-HQm-Glu and $60 \mu \mathrm{M}$ RuBi-Glu. Vertical scale, $50 \mathrm{pA}$. Horizontal scale, $100 \mathrm{~ms}$. (b) Summary of the $N$-Me-HQm-Glu and RuBi-Glu evoked peak amplitude.

は24 時間経過後も自発的加水分解はみられず，非 常に高い加水分解安定性を有していることが明らか になった。さらに，N-Me-7-HQm 型ケージドグル タミン酸は, 暗所・室温かつ無溶媒条件において, 2 週間後も分解物に相当するアルコール体が生成し ない. RuBi 型ケージドグルタミン酸は保存条件が $-20^{\circ} \mathrm{C}$ であることや, Ellis-Davies らが報告した DEAQ450 型ケージドグルタミン酸は，室温で安定 な時間が 5 時間であることを踏まえると, ${ }^{13)}$ 筆者ら が開発した $N$-Me-7-HQm 型ケージドグルタミン酸 は，非常に高い加水分解安定性と操作性を備えてお り，光刺激によってのみグルタミン酸の放出が起こ るケージド化合物であることが明らかになった。

\section{4. おわりに}

以上，本稿では筆者らが最近見い出した $N$-メチ ル-7-ヒドロキシキノリニウム骨格をクロモフォア とする光感受性保護基の創製と，それを応用した青 色光での活性化能を有するケージドアミノ酸につい て概説した。 $N$-メチル-7-ヒドロキシキノリニウム 型光感受性保護基の開発は，7-ヒドロキシキノリン 骨格の窒素原子を $N$-メチル化する非常にシンプル な分子変換によって達成された。従来の光感受性保 護基は，生物活性分子に導入し，精製後そのまま用 いるために，その光活性化能は導入した光感受性保 護基に依存するが，筆者らが開発した $N$-メチル7-キノリニウム型光感受性保護基では，生物活性分 子と結合したのちに，N-アルキル化によって可視 光活性化能を付与している点が特徵である。この合
成後期における $N$-アルキル化による高度化は，目 的に適したアルキル化剂を作用させることで，理論 上，吸収波長の長波長化やモル吸光係数の増大など 光学特性の高度化に加え, 水溶性の向上や分子認識 能の付与など，様々な機能を持つた官能基を“後付 け”することが可能である。これは反応性共通中間 体から多様な機能を持った誘導体合成を可能にし， 魅力的なケージド化合物ライブラリーの構築に有利 な合成戦略と言える。今後は，N-メチル-7-ヒドロ キシキノリニウム型ケージド化合物を用いたケミカ ルバイオロジー研究を実施するとともに，N-アル キルキノリニウム化合物の特性を最大限に活かした 光機能性分子を開発していきたい.

これまで述べてきたように，光毒性の低減が期待 できる可視光による 1 光子励起反応を利用するケー ジド化合物は，高額なレーザーや特殊な実験環境を 必要とせず，入手容易な LED 光源で生命機能メ力 ニズムを制御する化学的手法を提供することから, 今後もケージド化合物開発の 1 つの方向性となるで あろう。しかし，光感受性保護基やケージド化合物 の創製研究において，確立された方法論はなく（計 算科学的手法が大きな助けとなるのは言うまでもな (が)，その多くは研究者の経験と試行錯誤に依存 するも事実である．開発の実現性の観点からは，本 稿で紹介した 7- ヒドロキシキノリン型を $N$-アルキ ル化した $N$-メチル-7-キノリニウム型や，クマリニ ルメチル型の $\pi$ 共役系を伸長した DEAQ450 型, 重原子効果を巧夕に利用した BODIPY 型の開発に 
みられるように, 既存の光感受性保護基や蛍光分子 の構造修飾に基づく分子設計戦略は，実現性の高い アプローチと言える。一方で, 光感受性保護基を構 成する有機化合物は, 本来無限の構造的並びに機能 的多様性を持っており，これはケージド化合物が合 成化学を起点に，目的に応じてさらに進化できる可 能性を明確に示している，今後，多くの研究者に よって更なる工夫が重ねられ，新たな光感受性保護 基やケージド化合物が見い出され，これらを起点と する光操作技術が生物活性分子の機能を自在に制御 するモダリティとして確立されることを期待したい.

\section{謝辞本研究は静岡大学工学部ケミカルバイオ} ロジーグループにて実施されたものであり，間瀬暢 之教授，佐藤浩平助教を始め多くのメンバーに多大 なご支援及びご助言を頂きました。また，紹介した 一部の研究については, 東邦大学理学部の古田寿昭 教授, 生理学研究所の吉村由美子教授との共同研究 の成果であり, 多大な貢献を頂いた関連の皆様にこ の場を借りて深く感謝致します。

利益相反＼cjkstart開示すべき利益相反はない.

\section{REFERENCES}

1) Brieke C., Rohrbach F., Gottschalk A., Mayer G., Heckel A., Angew. Chem., Int. Ed., 51, 8446-8476 (2012).

2) Klán P., Šolomek T., Bochet C. G., Blanc A., Givens R., Rubina M., Popik V., Kostikov A., Wirz J., Chem. Rev., 113, 119-191 (2013).

3) Šolomek T., Wirz J., Klan P., Acc. Chem. Res., 48, 3064-3072 (2015).

4) Narumi T., Takano H., Ohashi N., Suzuki A., Furuta T., Tamamura H., Org. Lett., 16, 1184-1187 (2014).

5) Takano H., Narumi T., Ohashi N., Suzuki A., Furuta T., Nomura W., Tamamura H., Tetrahedron, 70, 4400-4404 (2014).

6) Takano H., Narumi T., Nomura W., Furuta T., Tamamura H., Org. Lett., 17, 5372-5375 (2015).

7) Abe M., Chitose Y., Jakkampudi S., Thuy P. T. T., Lin Q., Van B. T., Yamada A., Oyama R., Sasaki M., Katan C., Synthesis, 49, 33373346 (2017).
8) Olejniczak J., Carling C.-J., Almutairi A., J. Control. Release, 219, 18-30 (2015).

9) Fino E., Araya R., Peterka D. S., Salierno M., Etchenique R., Yuste R., Front. Neural Circuits, 3, 2 (2009).

10) Umeda N., Takahashi H., Ueno T., Komatsu T., Terai T., Hanaoka K., Nagano T., Urano Y., ACS Chem. Biol., 9, 2242-2246 (2014).

11) Slanina T., Shrestha P., Palalo E., Kand D., Peterson J. A., Dutton A. S., Rubinstein N., Weinstain R., Winter A. H., Klán P., J. Am. Chem. Soc., 139, 15168-15175 (2017).

12) Fournier L., Aujard I., Saux T. L., Maurin S., Beaupierre S., Baudin J.-B., Jullien L., Chem. Eur. J., 19, 17494-17507 (2013) .

13) Olson J. P., Kwon H.-B., Takasaki K. T., Chiu C. Q., Higley M. J., Sabatini B. L., EllisDavies G. C. R., J. Am. Chem. Soc., 135, 5954-5957 (2013).

14) Lin Q., Yang L., Wang Z., Hua Y., Zhang D., Bao B., Bao C., Gong X., Zhu L., Angew. Chem., Int. Ed., 57, 3722-3726 (2018).

15) Fedoryak O. D., Dore T. M., Org. Lett., 4, 3419-3422 (2002).

16) Davis M. J., Kragor C. H., Reddie K. G., Wilson H. C., Zhu Y., Dore T. M., J. Org. Chem., 74, 1721-1729 (2009).

17) Badugu R., Kostov Y., Rao G., Tolosa L., Biotechnol. Prog., 24, 1393-1401 (2008).

18) Senda N., Miwa Y., Tanaka J., Momotake A., Arai T., Chem. Lett., 39, 308-310 (2010).

19) Senda N., Momotake A., Arai T., Heterocycles, 81, 2343-2350 (2010).

20) Suzuki A. Z., Watanabe T., Kawamoto M., Nishiyama K., Yamashita H., Ishii M., Iwamura M., Furuta T., Org. Lett., 5, 48674870 (2003).

21) Quann E. J., Merino E., Furuta T., Huse M., Nat. Immunol., 10, 627-635 (2009) .

22) Kim T. G., Topp M. R., J. Phys. Chem. A, 108, 10060-10065 (2004).

23) Canepari M., Nelson L., Papageorgiou G., Corrie J. E., Ogden D., J. Neurosci. Methods, 112, 29-42 (2001).

24) Furuta T., Wang S. S. H., Dantzker J. L., Dore T. M., Bybee W. J., Callaway E. M., Denk W., Tsien R. Y., Proc. Natl. Acad. Sci. USA, 96, 1193-1200 (1999). 